\title{
The Role of the Undergraduate Student in Teaching and Learn- ing Biology
}

\author{
Terry L. Hufford \\ Department of Biological Sciences, The George Washington University, Washington, DC, USA
}

Received: December 7, 2010 / Accepted: December 13, 2010

\begin{abstract}
$T$

he possible roles of the undergraduate student as instructor and colleague in the teaching of undergraduate biology are discussed. These roles include laboratory UTA, peer instructor, collaborative group facilitator, tutor, learning facilitator, and associate in learning and teaching. The latter role involves the undergraduate student in course development and design.
\end{abstract}

\section{Introduction}

Traditionally the role of an undergraduate student is that of a learner: the recipient of teaching. However, for most of my $45+$ years of teaching I have utilized undergraduate students as aides or colleagues in course instruction. I have discovered I could give these students increased responsibility in classroom instruction and in course development and design.

The use of undergraduate students in the delivery of instruction is certainly not new or innovative. Fingerson and Culley (2001) state that the use of UTA's is common in many colleges and universities and across many disciplines. However, a search of the literature might indicate that the practice is not quite as prevalent in the sciences. In the field of biology it seems quite common to find undergraduate students utilized as laboratory instructors, particularly in collaboration with a GTA (Smith et al.,
2004). Some programs use students enrolled in a teacher education program (Greene 2000).

The use of UTA's in the lecture portion of science courses is perhaps not as prevalent. Kopp (2000) discusses the use of undergraduate peer assistants in a large physics lecture course. Maytag (2004) discusses the impact of using undergraduate students to teach astronomy students. The use of an undergraduate student as a colleague in the process of course development is not nearly as common a practice.

\section{Discussion}

\section{The Laboratory Teaching Assistant (UTA)}

The general use of undergraduate students in the biology laboratory makes a detailed review redundant here. Smith, et al (2005) discuss the use of UTA's as members of their teaching team in the design of an introductory biology course incorporating active learning.

Greene (2000) discusses the use of pre-service teacher education students as teaching interns. In their paper Conceptual Change in the Undergraduate Biology Teaching Laboratory: A "Type Specimen" Case Study, Jones and Eichinger (2005) note the use of UTA's in their laboratory. 


\section{Collaborative Group Facilitators}

Some students, as a factor of their cultural and educational experiences, had a very difficult time with the critical thinking and higher level cognition associated with my introductory biology course for science majors at George Washington University. Too many were not successful in passing the course and this came to be intolerable to me. Making the course less rigorous was not an option, thus alternative methods of instruction had to be utilized that made the material accessible and understandable for students whose approach to learning differed from my more conceptual, critical thinking approach to teaching.

The results of my findings and solutions were presented in BioScience (Hufford 1991). Among the keys was to take the concept of group learning I had established for the laboratory and apply it to the course as a whole. The class was subdivided into collaborative groups of six students each. These groups were expected to meet outside of regular class times. As I did not have the time to meet personally with each group I decided this would be an excellent way to utilize undergraduate students as Collaborative Group Facilitators (CGFs).

Training of CGF's was much more extensive than for the UTA. They were given an admittedly brief introduction to the nature of collaborative learning and to the concept of facilitation. In addition, weekly meetings with me as the course instructor helped prepare the facilitator for their weekly sessions. With the cooperation and assistance of the George Washington University Multicultural Student Services Office, their students were required to attend the weekly group sessions. The results of this and other intervention approaches indicated a remarkable improvement in performance, not only for students of educationally substandard backgrounds but for all students that attended the sessions.

A similar use of UTA's is in peer instruction, although the distinction between a collaborative group facilitator and a peer instructor may not be significant. Fagan, Crouch and Mazur (2000) discuss the use of peer instructors in a variety of classrooms, but focus on Physics. Deb Burman (date unknown) utilized peer instruction in cell biology while Schmieg, Cataldi and Dries (2000) refer to the use of peer instructors in the development of honors instruction in biology. Allen and her collaborators (1999, $2001,2005)$ were instrumental in the introduction of the use of peer facilitators into biology instruction. Eberlein (2008), Lewis and Lewis 9(2008), Micari, et al (2006, 2010), Sarquis, et al (2001) and Smith, et al (2004) are others who discuss the use of peer tutors (mentors, facilitators) in the sciences. Harris and Sandor ( 2007) mention the use of peer instruction in e-learning.

\section{Learning Facilitators}

I had planned on "officially" retiring after a three year special appointment (received following my initial retirement and grant of emeritus status) had ended. However, several members of the Biology faculty were on sabbatical and I was asked if I would stay on another year to teach the non-majors biology course. I had not taught a large enrollment non-majors course in many years.
My immediate challenge was to present a rigorous course that emphasized those aspects I have always believed to be important: critical thinking and the ability to integrate information in meaningful ways while maintaining student interest and providing a reasonable opportunity to earn an acceptable grade in the course. My reputation worked both for and against me in this endeavor. Students knew I was a Distinguished Teaching Professor but they also knew I was a demanding teacher. For first-years this was somewhat intimidating. I realized that some students might consent to e-mail me but few would come to my office, even though I encouraged, indeed welcomed and desired, that they do so making this clear both in lecture and in course material.

I decided that upper level undergraduate students might be able to bridge that gap between student and instructor. I had no funds available to pay such a group so I contacted former students and asked if they would be willing to work with me on a volunteer basis as "Learning Facilitators (LF's)." A number responded in the affirmative and I selected 16 individuals, each being responsible for a group of $16-24$ students. The easiest way to form the groups was to utilize groups already formed by the laboratory section delineations. Each LF was assigned one group of laboratory students. I met with the LF's prior to the beginning of classes to describe the program I had in mind and to provide background in the process of facilitation. Given that all the Facilitators were volunteers, I felt somewhat restricted in what I could require of them. Face-to-face meetings with the students seemed to be prohibitive because of the time demand. I therefore determined that all contact would be via e-mail. The existence and nature of the program together with the e-mail address of each LF was given to class members verbally and on their Blackboard link. The students were told to expect an email from their facilitator in which the facilitator would introduce themselves and provide a brief synopsis of the interactions they expected to take place over the course of the semester.

\section{Fall Semester}

Each Learning Facilitator was expected to communicate at least once each week with each of their assigned students. These communications encouraged the student to discuss with the facilitator any problems or questions the student had in regard to lecture material or their expectations of the course. In addition, each week the Facilitator would compose an open-ended critical thinking question that they e-mailed to their students. The question introduced the student to the thought process they would

Table 1. Final grade in course as compared to number of interactions per week with Learning Facilitator.

\begin{tabular}{|c|c|}
\hline $\begin{array}{c}\text { Final } \\
\text { Grade }\end{array}$ & $\begin{array}{c}\text { \% Interaction } \\
\text { Based on 1/wk }\end{array}$ \\
\hline $\mathrm{A}^{-}-\mathrm{A}$ & 69 \\
\hline $\mathrm{B}^{-}-\mathrm{B}^{+}$ & 46 \\
\hline $\mathrm{C}^{-}-\mathrm{C}^{+}$ & 46 \\
\hline F $-\mathrm{D}^{+}$ & 31 \\
\hline
\end{tabular}


need to utilize in answering questions I might give on examinations and gave the student some indication of the subject matter required. The answer was e-mailed back to the Facilitator. The Facilitator would then critique the answer and get back to the student if some lack of information, misinformation, or misapplication of information existed. As encouragement to the student to participate in the process, the student would receive one bonus point for each response returned. A total of 15 points could thus be earned over the course of the semester and these were added to the students total points earned in the course. The results of the interaction are given in Table 1.

While there are significant differences between high, middle and low grades, these results cannot be interpreted in a simple, straightforward way. For example, students that corresponded with their LF on a regular basis (at least once each week 90 - $100 \%$ of the time) had an average grade in the course of 3.0 on a 4.0 basis. Those that did not correspond at all or corresponded less than $10 \%$ of the time had an average grade of 2.87. The difference between these means was not significant as the standard deviation for each group was quite high. Grades ranged from $F$ to $A$ for each group. In addition, a control of sorts was accidentally provided as one LF did not correspond at all with her students and did not inform either myself or the Teaching Associate that she was not doing so. In addition, a few students were inadvertently not assigned to any LF. This group of 33 students had an average final grade of $2.3\left(\mathrm{C}^{+}\right)$while the other 209 students who at least had the option of communicating with a Learning Facilitator had an average final grade of 2.7 (B-). While this might appear to be a significant difference, again the standard deviation was great and grades ranging from $A$ to $F$ were found for both groups.

Feedback from both the students and the LF's revealed several things. Both students and facilitators would have preferred the option for face to face meetings, either in groups or one-on-one. There was considerable difference between the LF's in regard to their ability for significant interaction with their students, within the framework of the program objectives. The rating of the program by the students was directly related to the ability of their LF to provide significant and helpful interaction. Finally, all LF's were not equally competent in making up significant critical thinking questions. Although I had suggested the LFs should work together in devising such questions, many ignored this advice.

\section{Spring Semester}

Spring semester provided an opportunity to work on several of the problems apparent in the fall semester. I taught a single small enrollment section. This allowed for several changes in presentation style. Lecture time was greatly reduced and the section became essentially problem based. The course included considerable writing with short papers called Concept Papers due every other week and major Position Papers due at midsemester and at the final. Secondly, the Department Chair provided funding to hire a Learning Facilitator. I selected Ms. Sherry Weinstein, a student in our Honors Program and one of the most outstanding Learning Facilitators from the Fall Semester. The class of 22 students was divided into six collaborative groups and Ms. Weinstein met at least once weekly with each group. In addition, the students could contact her for individual appointments if they wished. I was available for individual meetings and set up group sessions before the mid-term and final examination that students could attend if they wished to review material or ask questions. We were both available to talk about the papers, content information, or content application, that is, critical thinking aspects.

As with educational research in general, it is difficult to analyze the results in any systematic or quantitative way. In a qualitative sense, the course was a great success. Student response was quite positive. They enjoyed the course and believed they learned a great deal about biology, particularly the role of biology in societal and public issues. In regard to outcome, as measured by final grade, the mean was $3.2 / 4.0$, a significant difference from the 2.6/4.0 earned by the class Fall Semester. However, one can question the significance of the outcome. Registration for the section was a self-selection process. Did the better students select this special section? Nine of the 22 students in the course Spring Semester had taken the first half of Introductory Biology in the Fall Semester. Those nine students had an average grade Fall Semester of 3.4/4.0, significantly better than the mean. Spring Semester that group of students earned a 3.5/4.0; slightly higher but certainly not significantly so. For them it would seem self-selection was a factor. Thirteen students had not taken the first half of the course. One might suspect that these students would be somewhat at a disadvantage, particularly as they would not have had the experience of taking my examinations. They did score somewhat lower, averaging 2.9/4.0. This was still higher than the mean grade for the Fall Semester group. Did the latter students also represent an aspect of self-selection? Was there deliberate selection of this section by inherently better students? These questions cannot be answered with any certainty.

The final grades in the course were the highest overall of any introductory biology course I have ever taught (other than Honors Biology). An average of almost a B+ was a full letter grade higher than the $\mathrm{C}+$ average typical for my introductory courses. Was this result simply the consequence of chance in having an outstanding group of students, was it due to course design, or was it due to the excellent work of Ms. Weinstein in her capacity as Learning Facilitator? There were no evaluative tools in place that would provide evidence by which the question could be answered.

\section{The Teaching Associate}

When I retired in 2001, the President of the George Washington University offered me a special 3-year appointment as Distinguished Teaching Professor. My responsibility was to work exclusively with aspects of undergraduate science education, particularly in the area of biological science. In part, a consequence of that appointment was the development of an introductory biology course for our Honors Program. In addition, with a grant from the Hewlett Packard Foundation, I developed a course for non-science majors called Biology in the City. The latter course utilized considerable community resources as teaching 
adjuncts and was completely Problem Based. It is, however, the former course, Honors Biology, that I will discuss.

Honors Biology was developed over the summer of 2001 and taught for the first time during the 2001-2002 academic year. It was reasonably well received but some obvious problems were noted both by me and by the students. The course involved discussion, but was still too much lecture based. Being a course open to all students, a balance had to be found between providing information necessary for students in our Pre-Med and Science programs while not overwhelming students in the social sciences, humanities, business, and international affairs areas.

During the year, I had many interesting and informative discussions with all the students in the course but one in particular stood out. Ms. Heather Spence was an extremely intelligent and multi-talented individual who was able to establish good rapport with members of her collaborative working group and with other students in the class. In addition she had many ideas and much insight into aspects of the learning environment. It seemed obvious to me that course revision could proceed in a much more efficient and effective way if her views, insight, and perceptions as a student could be incorporated and intercalated with my own views on course development. After she completed the course, I asked her if she would be interested in working with me in the revision and redevelopment of Honors Biology. I had no funding for her, so if she was to accept it would be in a volunteer capacity. She did accept and I named her Associate in Teaching \& Learning. We were able, with the cooperation of the Honors Program, to have her work recognized as Independent Study. Thus she was able to receive credit hours that would count towards her Honors requirements.

That summer and for the next two years Heather worked closely with me in course content and design, the development of assessment instruments for course and student assessment, and the development of discussion topics and criteria. In addition, during the academic year she was involved with in-class instruction and interacted with the students outside class, meeting with students individually to provide assistance with course materials and to ascertain problems or concerns they had with the course. These concerns were relayed back to me, without naming the individual that made them. In addition she worked with the collaborative groups, helping them with their group projects and acting in the role of facilitator. The close association and trust that Heather was able to establish with the students was extremely important to course improvement. She acted as a sort of "sounding board" which made it possible for on-the-fly changes. She helped in very significant ways to determine what was working and what was not working and offered her own ideas for changes that were generally complementary with my own.

By the third year of the course, and the final year of my three-year appointment, the course was recognized as an innovative, interesting and challenging course in introductory biology. Much of the credit for this positive development goes to Ms. Spence.

That did not end my association with Ms. Spence nor did it end her commitment to the area of teaching and learning. She helped me in the coordination and implementation of the Learning Facilitators Program discussed previously.

\section{Conclusions}

While I have utilized many undergraduate students in different capacities in my courses during $45+$ years of teaching, most of the programs discussed in this paper are the result of my appointment as Distinguished Teaching Professor. This allowed additional time to consider, develop and implement the several programs. I have found that undergraduate students can contribute much to excellence in teaching. I encourage all instructors of introductory biology to consider the expanded use of undergraduate students in their courses and I stand ready to assist in this process.

\section{References}

Allen D and K Tanner (2005) Infusing active learning into the large-enrollment biology class: Seven strategies, from the simple to complex. Cell Biol Educ 4(4): 262-268.

Allen DE and HB White (1999) A few steps ahead on the same path: using peer tutors in the cooperative learning classroom - a multilayered approach to teaching. J Coll Sci Teach 28: 299-302.

Allen DE and HB White (2001) Peer facilitators of in-class groups: adapting problem-based learning to the undergraduate setting. In: Student Assisted Teaching: A Guide to Faculty-Student Teamwork, ed. JE Miller, JE Groccia and MS Miller. Bolton, MA: Anker Publications. Clark, Deborah. Undergraduate teaching intern. http://biology.science.oregonstate.edu/PDF/ugteachinterm.pdf

DebBurnam and $K$ Shubhik (date unknown). Supplemental peer instruction. http://campus.lakeforest.edu/ debburnam/Peerteacher. html\#lake forest.

Eberlein, Thomas et al. (2008). Pedagogies of engagement in science. Biochem Mol Biol Educ 36 (4): 262-273.

Fagan, Adam, Crouch, Catherine H. and Mazur, Eric. (2000). Peer instruction: results from a range of classrooms. The Physics Teacher 40: 206-209.

Fingerson, Laura and Culley, Aaron B. (2001). Collaborators in teaching and learning: undergraduate teaching assistants in the classroom. Teaching Sociology 29(3): 299-315.

Greene, Janice Schnake. (2000). A biology laboratory internship program. The American Biology Teacher 62(2): 108-1 12.

Harris, N. \& Sandor, M. (2007). Developing online discussion forums as student centred peer e-learning environments. In ICT: Providing choices for learners and learning. Proceedings Ascilite Singapore 2007. http://www.ascilite.org.au/conferences/singapore07/ procs/harris.pdf

Hufford, Terry L. (1991). Increasing academic performance in an introductory biology course. BioScience 41 (2): 107-108.

Jones, Dorothy A. and Eichinger, David C. (2005). Conceptual change in the undergraduate biology teaching laboratory: a "type specimen" case study. http://www.educ.sfu.ca/narstsite/ conference/98conference/jones.

Kopp, Sacha E. (2000). Undergraduate peer assistants in a large lecture course. Phys. Educ 35: 423-427.

Lewis, Scott E. and Lewis, Jennifer E. (2008) Seeking effectiveness and equity in a large college chemistry course: an HLM investigation of Peer-Led Guided Inquiry. J Res Sci Teach 45: 794-811.

Maytag, C.P. (2004). The impact of using undergraduate students to teach other students. AAS 204th Meeting. Bulletin of the American Astronomical Society 36(2).

Micari, Marina, Gould, Amy Knife and Lainez, Louie. (2010). Becoming a leader along the way: embedding leadership training into a 
large-scale peer-learning program in the STEM disciplines. J Coll Stud Dev 51(2): 218-230.

Micari, Marina, Streitwieser, Bernhard and Light, Gregory (2006) Undergraduates leading undergraduates: peer facilitation in a science workshop program. Innovative Higher Education 30(4): 269-288.

Sarquis, J.L., Dixon, L.J., Gosser, D.K., Kampmeier, J.A., Roth, V., Strozak, V.S., and Varma-Nelson, P. (2001). The Workshop Project: peer-led team learning in chemistry. In: Student-Assisted Teaching: A Guide to Faculty-Student Teamwork, ed. J.E. Miller, J.E. Groccia and M.S. Miller. Bolton, MA: Anker Publishing.
Schmeig, Florence, Cataldi, Drin, and Dries, Dan. (2000). Honors instruction in biology. About Teaching 54, spring 2000. http://www.edel. edu/cte/aboutteach/spring00/schmieg.html

Smith, Tania. (2007). Integrating undergraduate peer mentors into liberal arts courses: a pilot study. Innov High Educ 43(1): 49-63.

Smith, Ann C., Stewart, Richard, Shields, Patricia, Hayes-Klosterides, Jennifer, Robinson, Paulette, and Yuan, Robert. (2004). Introductory biology courses: a framework to support active learning in large enrollment introductory science courses. Cell Biology Education 4:143156. 